\title{
Hepatitis B Virus Core Promoter Double Mutations (A1762T, G1764A) Are Associated with Lower Levels of Serum Dihydrolipoyl Dehydrogenase
}

\author{
Zhi-Hua Jiang ${ }^{\mathrm{a}}$ Qin-Yan Chen ${ }^{\mathrm{a}}$ Tim J. Harrison ${ }^{\mathrm{b}}$ Guo-Jian $\mathrm{Li}^{\mathrm{c}}$

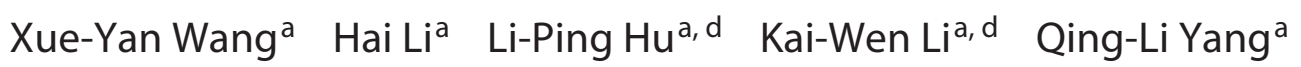 \\ Chao Tan $^{\text {a }}$ Zhong-Liao Fang ${ }^{\text {a }}$ \\ ${ }^{a}$ Guangxi Zhuang Autonomous Region Center for Disease Prevention and Control, Guangxi Key Laboratory for the \\ Prevention and Control of Viral Hepatitis, Nanning, Guangxi, PR China; ' Division of Medicine, UCL Medical School,

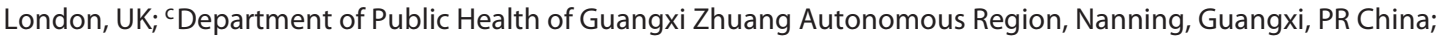 \\ ${ }^{\mathrm{d}}$ School of Preclinical Medicine, Guangxi Medical University, Nanning, Guangxi, PR China
}

\section{Key Words}

Hepatitis B virus · Basal core promoter · Mutations .

Dihydrolipoyl dehydrogenase $\cdot$ Proteomics

\begin{abstract}
Objectives: The aim of this study was to identify serum proteins with differential concentrations between hepatocellular carcinoma (HCC) patients and HBsAg asymptomatic carriers among individuals infected with hepatitis $B$ virus (HBV) with basal core promoter (BCP) double mutations (A1762T, G1764A). Methods: iTRAQ and liquid chromatography-tandem mass spectrometry were used to identify differentially expressed protein, and an ELISA test was used for the validation test. Results: The total number of proteins identified was 1,125 , of which 239 showed statistically significant differences in their expression. The relative concentrations of serum dihydrolipoyl dehydrogenase (DLD), which showed the most significant correlation with liver diseases and infection, were significantly lower in HCC patients than asymptomatic $\mathrm{HBsAg}$ carriers and individuals negative for $\mathrm{HBsAg}$. However, only the difference between HCC patients with $B C P$ double mutations and $\mathrm{HBsAg}$-negative individuals could be confirmed by ELISA. Meanwhile, we found that the concentrations of serum DLD in those infected with HBV
\end{abstract}

with $B C P$ double mutations were significantly lower than in individuals with the wild-type BCP. However, the difference in the concentrations of serum DLD between individuals with wild-type $B C P$ and those negative for $\mathrm{HBsAg}$ was not significant. Conclusions: HBV with BCP double mutations are associated with lower concentrations of serum DLD.

(C) 2016 The Author(s)

Published by S. Karger AG, Basel

\section{Introduction}

Hepatocellular carcinoma (HCC) is the most common primary malignancy of the liver. Globally, it is the fifth most common cancer in men, and seventh among women, with over half a million new cases diagnosed annually worldwide [1]. The great majority of liver cancer $(>80 \%)$ occurs in either sub-Saharan Africa or in Eastern Asia, with one country alone, China, accounting for over $50 \%$ of cases [2]. When specific diagnostic tests for hepatitis B virus (HBV) infection were introduced in the early 1970s, it became clear that there is a strong etiological association between chronic HBV infection and the development of HCC [3]. However, the mechanisms of oncogenesis remain obscure. 
HBV has a circular, partially double-stranded DNA genome of about 3,200 nt with four open reading frames (ORFs), namely the core/precore, polymerase, surface and X ORFs [4]. Transcription of the four ORFs is controlled by the core, large surface, major surface and X promoters. The core promoter, located between nt 1,575 and 1,849 , consists of the basal core promoter (BCP; nt 1,7431,849 ) and the upper regulatory region (nt 1,613-1,742) [5]. The genome replicates via an RNA intermediate and the lack of proofreading during reverse transcription of the pregenomic RNA favors the development of sequence variants during long-term HBV replication [6]. One of the most critical changes is the appearance of double mutations at nt 1,762 (A-T) and 1,764 (G-A) in the BCP [7]. This has been reported to be associated with the pathogenesis of progressive liver disease, including HCC [811 .

In our initial studies $[9,10]$, we found BCP double mutations in HBV from $96 \%$ of HCC patients, but only $24 \%$ of controls, from Guangxi, China. In order to determine the value of screening HBsAg carriers for virus with BCP double mutations as a marker of extremely high risk of developing HCC, we are carrying out a prospective cohort study in Long An county, southern Guangxi. Within this cohort, we found that $93.3 \%$ of the male HCC cases were infected with the mutant [12]. Clearly, the double mutations are an etiological factor of HCC. The prevalence of $\mathrm{BCP}$ double mutations in the population where the cohort was established is $53 \%$. It is also clear that not all of those infected by HBV with BCP double mutations ultimately develop HCC. What is the difference between those who will develop HCC and those who will not, among individuals infected with HBV with BCP double mutations? The answer will enable us to understand further the mechanisms of oncogenesis of $\mathrm{HBV}$ and, probably, obtain a good biomarker for HCC.

The aim of this study was to identify serum proteins with differential concentrations among HCC patients infected with HBV with BCP double mutations, asymptomatic HBsAg carriers with BCP double mutations and individuals negative for HBsAg, using iTRAQ (isobaric tags for relative and absolute quantification) [13] and liquid chromatography-tandem mass spectrometry.

\section{Materials and Methods}

\section{Serum Sample Collection}

Serum samples were collected from patients from Guangxi Medical University and the Long An cohort [12]. The patients who provided serum samples for proteomic analysis and for the valida- tion of the significantly differentially expressed protein included HCC cases, asymptomatic HBsAg carriers and HBsAg-negative individuals. All blood samples were incubated at room temperature for $30 \mathrm{~min}$ and centrifuged for $10 \mathrm{~min}$ at 3,000 rpm $(1,600 \mathrm{~g})$. The serum samples were divided into three aliquots and processed independently as biological triplicates to assess the reproducibility of the data. The sera were stored at $-80^{\circ} \mathrm{C}$ until the analysis.

Informed consent in writing was obtained from each individual. The study protocol conformed to the ethical guidelines of the 1975 Declaration of Helsinki and was approved by the Guangxi Institutional Review Board.

\section{Serological Testing and HBV DNA Amplification and}

Sequencing

The tests for HBsAg, HBeAg/anti-HBe and alanine aminotransferase (ALT) in serum, and amplification of the BCP of HBV DNA and nucleotide sequencing were as described previously [12].

\section{Protein Preparation}

To reduce the complexity of the samples, highly abundant proteins were depleted using ProteoMiner ${ }^{\mathrm{TM}}$ kits (Bio-Rad Laboratories, Hercules, Calif., USA) according to the manufacturer's protocol. Briefly, the samples were eluted in Lysis buffer ( $7 \mathrm{M}$ urea, 2 $\mathrm{M}$ thiourea, 4\% CHAPS, $40 \mathrm{~mm}$ Tris- $\mathrm{HCl}, \mathrm{pH} 8.5)$ and reduced with $10 \mathrm{mM}$ DTT (final concentration) at $56^{\circ} \mathrm{C}$ for $1 \mathrm{~h}$, followed by alkylation with $55 \mathrm{mM}$ IAM (final concentration) for $1 \mathrm{~h}$ in the dark. The reduced and alkylated protein mixtures were precipitated by adding $4 \times$ volume of chilled acetone at $-20^{\circ} \mathrm{C}$ overnight. After centrifugation at $4^{\circ} \mathrm{C}, 30,000 \mathrm{~g}$, the pellet was dissolved in 0.5 M TEAB (Applied Biosystems, Milan, Italy) and sonicated on ice. After centrifuging at $30,000 \mathrm{~g}$ at $4^{\circ} \mathrm{C}$, an aliquot of the supernatant was taken for the determination of protein concentration using the Bradford method with BSA as a standard [14]. The proteins in the supernatants were kept at $-80^{\circ} \mathrm{C}$ for further analysis.

\section{iTRAQ Labeling and SCX Fractionation}

Total protein $(100 \mu \mathrm{g})$ was taken from each sample solution and digested with Trypsin Gold (Promega, Madison, Wis., USA), with a ratio of protein:trypsin of $30: 1$, for $16 \mathrm{~h}$ at $37^{\circ} \mathrm{C}$. After trypsin digestion, the peptides were dried by vacuum centrifugation. The peptides were reconstituted in $0.5 \mathrm{M}$ TEAB and processed according to the manufacturer's protocol for the 8-plex iTRAQ reagent (Applied Biosystems). Briefly, 1 unit of iTRAQ reagent was thawed and reconstituted in $24 \mu \mathrm{l}$ of isopropanol. Peptides were labeled with 116, 118 and 121 iTRAQ tags by incubation at room temperature for $2 \mathrm{~h}$. The labeled peptide mixtures were then pooled and dried by vacuum centrifugation.

SCX (strong cation exchange) chromatography was performed with an LC-20AB HPLC Pump system (Shimadzu, Kyoto, Japan). The iTRAQ-labeled peptide mixtures were reconstituted with $4 \mathrm{ml}$ of buffer $\mathrm{A}$ ( $25 \mathrm{mM} \mathrm{NaH}_{2} \mathrm{PO}_{4}$ in $\left.25 \% \mathrm{ACN}, \mathrm{pH} 2.7\right)$ and loaded onto $4.6 \times 250 \mathrm{~mm}$ Ultremex SCX columns containing $5-\mu \mathrm{m}$ particles (Phenomenex). The peptides were eluted at a flow rate of 1 $\mathrm{ml} / \mathrm{min}$ with a gradient of buffer A for $10 \mathrm{~min}, 5-60 \%$ buffer B (25 $\mathrm{mM} \mathrm{NaH}_{2} \mathrm{PO}_{4}, 1 \mathrm{M} \mathrm{KCl}$ in $25 \% \mathrm{ACN}, \mathrm{pH} 2.7$ ) for $27 \mathrm{~min}$, and $60-$ $100 \%$ buffer B for $1 \mathrm{~min}$. The system was then maintained at $100 \%$ buffer B for $1 \mathrm{~min}$ before equilibrating with buffer A for $10 \mathrm{~min}$ prior to the next injection. Elution was monitored by measuring the absorbance at $214 \mathrm{~nm}$ and fractions were collected every $1 \mathrm{~min}$. 
The eluted peptides were pooled into 20 fractions, desalted with a Strata X C18 column (Phenomenex) and vacuum dried.

\section{LC-ESI-MS/MS Analysis Based on Triple TOF 5600}

LC-ESI-MS/MS (liquid chromatography-electrospray ionization tandem mass spectrometry) analysis based on Triple TOF (time-of-flight) 5,600 was performed. Each fraction was resuspended in buffer A ( $5 \% \mathrm{ACN}, 0.1 \% \mathrm{FA})$ and centrifuged at 20,000 $g$ for $10 \mathrm{~min}$; the final concentration of peptide was about $0.5 \mu \mathrm{g} /$ $\mu \mathrm{l}$ on average. Ten microliters of supernatant was loaded onto an LC-20AD nanoHPLC (Shimadzu, Kyoto, Japan) by the autosampler onto a $2-\mathrm{cm} \mathrm{C18} \mathrm{trap} \mathrm{column.} \mathrm{The} \mathrm{peptides} \mathrm{were} \mathrm{then} \mathrm{eluted}$ onto a $10-\mathrm{cm}$ analytical C18 column (inner diameter $75 \mu \mathrm{m}$ ) packed in-house. The samples were loaded at $8 \mu \mathrm{l} / \mathrm{min}$ for $4 \mathrm{~min}$, then the $35-\mathrm{min}$ gradient was run at $300 \mathrm{nl} / \mathrm{min}$ starting from 2 to $35 \%$ B (95\% ACN, 0.1\% FA), followed by a 5-min linear gradient to $60 \%$, then a 2 -min linear gradient to $80 \%$, maintenance at $80 \%$ $\mathrm{B}$ for $4 \mathrm{~min}$, and finally a return to $5 \%$ for $1 \mathrm{~min}$.

Data acquisition was performed with a Triple TOF 5600 system (AB SCIEX, Concord, Ont., Canada) fitted with a Nanospray III source (AB SCIEX) and a pulled quartz tip as the emitter (New Objectives, Woburn, Mass., USA). Data were acquired using an ion spray voltage of $2.5 \mathrm{kV}$, curtain gas of $30 \mathrm{psi}$, nebulizer gas of $15 \mathrm{psi}$, and an interface heater temperature of $150^{\circ} \mathrm{C}$. The MS was operated with a reverse phase greater than or equal to 30,000 full width at half maximum for TOF MS scans. For IDA, survey scans were acquired in $250 \mathrm{~ms}$ and as many as 30 product ion scans were collected if exceeding a threshold of 120 counts/s and with a $2+$ to $5+$ charge state. The total cycle time was fixed to $3.3 \mathrm{~s}$. The Q2 transmission window was $100 \mathrm{Da}$ for $100 \%$. Four time bins were summed for each scan at a pulser frequency value of $11 \mathrm{kHz}$ through monitoring of the $40-\mathrm{GHz}$ multichannel TDC detector with four-anode channel detection. A sweeping collision energy setting of $35 \pm 5 \mathrm{eV}$ coupled with iTRAQ adjust rolling collision energy was applied to all precursor ions for collision-induced dissociation. The dynamic exclusion was set for $1 / 2$ of the peak width (15 s) and then the precursor was refreshed off the exclusion list.

\section{Data Analysis}

Mass spectra from the 20 fractions were combined into one MGF (Mascot generic format) file, and the MGF file was searched against the International Protein Index (IPI) human sequence databases (version 3.87, human, 91,464 sequences) using Mascot software (version 2.3.02; Matrix Science, London, UK). The search parameters were as follows: the fixed modifications were carbamidomethyl (C), iTRAQ8plex (N-term) and iTRAQ8plex (K), and the variable modifications were Gln $\rightarrow$ pyro-Glu (N-term $Q)$, oxidation (M) and iTRAQ8plex (Y). The peptide mass tolerance was $0.05 \mathrm{Da}$ and fragment mass tolerance was $0.1 \mathrm{Da}$. Trypsin was chosen as the enzyme with one missed cleavage allowed; an automatic decoy database search strategy was employed to estimate the FDR (false discovery rate). In the final search results, the FDR was $<0.05$. All identified peptides had an ion score above the Mascot peptide identity threshold and a protein was considered identified if at least one such unique peptide match was apparent for the protein. For protein quantitation, the filters were set as follows: 'median' was chosen for the protein ratio type; the minimum precursor charge was set to $2+$ and minimum peptide was set to 2; only unique peptides were used to quantify proteins. The median intensities were set as normalization and outliers were removed automatically.
Proteins with a 1.2 -fold or more change and $\mathrm{p}$ value $<0.05$ were considered as differentially expressed proteins. The logarithm of the ratio to base 2 below zero was considered to be downregulated, whereas those above zero were considered upregulated. Gene Ontology (GO) functional classifications were analyzed with Blast2GO software (http://www.blast2go.org/) and GO enrichment analysis was performed to identify GO terms that were significantly enriched in differentially expressed proteins.

\section{Validation of the Significantly Differentially Expressed Protein}

Dihydrolipoyl Dehydrogenase by ELISA

Dihydrolipoyl dehydrogenase (DLD) in sera was measured using an ELISA kit for DLD (Shanghai Xin Yu Biotech Co. Ltd, Shanghai, China) according to the manufacturer's instructions. The concentration of the protein in each sample was determined from a standard curve based on serial dilutions of the protein standard provided in the kit.

\section{Statistical Analysis}

Results for continuous variables with normal distributions are given as the mean \pm standard deviation (SD). Student's $t$ test was used to compare means between two groups. The results for continuous variables that were not normally distributed are given as the median (range) and were compared using the Mann-Whitney $\mathrm{U}$ test. Multiple linear regression analyses were performed to identify independent factors associated with concentrations of proteins identified in serum. If necessary, a logarithmic transformation was applied to concentrations of identified proteins prior to analysis to achieve an approximately normal distribution. All p values were two-tailed and $\mathrm{p}<0.05$ was considered to be significant. All statistical analyses were performed using the SPSS software (version 16.0; SPSS, Chicago, Ill., USA).

\section{Results}

\section{Demographics of the Subjects}

The total number of samples for proteomic analysis was 30, which consisted of the following: group A, 10 samples from HCC patients infected with $\mathrm{HBV}$ with BCP double mutations; group B, 10 samples from asymptomatic HBsAg carriers with BCP double mutations, and group C, 10 samples from HBsAg-negative individuals (table 1). The total number of samples for the validation of the significantly differentially expressed protein was 167, including 30 from HCC patients infected with $\mathrm{HBV}$ with BCP double mutations, 44 from asymptomatic HBsAg carriers infected with HBV with BCP double mutations, 47 from asymptomatic HBsAg carriers infected with $\mathrm{HBV}$ with wild-type BCP and $46 \mathrm{HBsAg-negative}$ individuals (table 2).

\section{Identification of Differentially Expressed Proteins}

The total number of proteins identified by iTRAQ was 1,125 , of which 239 showed statistically significant differ- 
Table 1. Demographics of subjects for iTRAQ testing

\begin{tabular}{lccccccc}
\hline Group & $\mathrm{n}$ & Male & Age, years & HBsAg $(+)$ & HBeAg $(+)$ & Anti-HBe $(+)$ & ALT $(\geq 40$ IU/ml $)$ \\
\hline A: HCC-DM & 10 & 10 & $48.8 \pm 8.7$ & 10 & 3 & 7 & 9 \\
B: ASC-DM & 10 & 10 & $48.5 \pm 6.6$ & 10 & 2 & 8 & 7 \\
C: HBsAg (-) & 10 & 10 & $47.9 \pm 9.9$ & 0 & 0 & 0 & 2 \\
\hline Total & 30 & 30 & $48.4 \pm 8.2$ & 20 & 5 & 15 & 18 \\
\hline
\end{tabular}

ASC = Asymptomatic HBsAg carriers; DM = double mutations.

Table 2. Demographics of subjects for validation testing

\begin{tabular}{lcccccc}
\hline Group & $\mathrm{n}$ & Male & Age, years & HBsAg $(+)$ & HBeAg $(+)$ & ALT $(\geq 40$ IU $/ \mathrm{ml}), \%$ \\
\hline HCC & 30 & 28 & $52.1 \pm 9.4$ & 30 & 8 & $66.7(20 / 30)$ \\
ASC-WT & 46 & 27 & $50.8 \pm 7.6$ & 46 & 14 & $15.2(7 / 46)$ \\
ASC-DM & 45 & 24 & $43.8 \pm 7.5$ & 45 & 6 & $37.8(17 / 45)$ \\
HBsAg (-) & 46 & 34 & $30.5 \pm 10.5$ & 0 & 0 & $4.3(2 / 46)$ \\
\hline Total & 167 & 113 & $43.6 \pm 12.3$ & 121 & 28 & $27.5(46 / 167)$ \\
\hline
\end{tabular}

ASC = Asymptomatic HBsAg carriers; $\mathrm{WT}=$ wild-type; $\mathrm{DM}=$ double mutations.

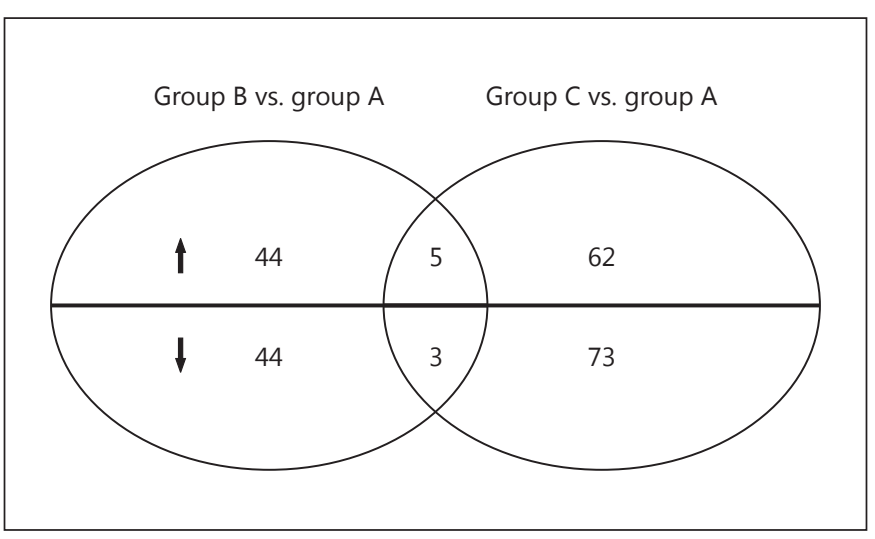

Fig. 1. The numbers of upregulated $(\uparrow)$ and downregulated $(\downarrow)$ proteins. The number of upregulated proteins was $44+5$ in group $\mathrm{A}$ versus $B$ and $62+5$ in group A versus $C$. The number of downregulated proteins was $44+3$ in group $A$ versus $B$ and $73+3$ in group $\mathrm{A}$ versus $\mathrm{C}$. The numbers of upregulated and downregulated proteins in both group A versus group B and group A versus group $\mathrm{C}$ were 5 and 3 , respectively. ences in their expression when the relative protein concentrations of group A and group B, or group A and group $\mathrm{C}$, were compared (fig. 1). The number of upregulated proteins in both group A versus group B and group $A$ versus group $C$ was 5 , and that of the downregulated proteins in both group A versus group B and group A versus group $\mathrm{C}$ was 3 (table 3 .).

\section{Validation of the iTRAQ Ratio by ELISA}

The protein which showed the most significant correlation with liver diseases and infection was validated by ELISA. In this study, DLD was selected for the validation. In the results from iTRAQ, the relative concentrations of DLD in HCC cases with BCP double mutations, asymptomatic HBsAg carriers with BCP double mutations and HBsAg-negative individuals were 10, 12.69 and 14.43, respectively.

The concentrations of serum DLD in HCC cases with BCP double mutations, asymptomatic HBsAg carriers with $\mathrm{BCP}$ double mutations and $\mathrm{HBsAg}$-negative individuals were $117.3 \pm 33.8,109.0 \pm 34.5$ and $205.1 \pm 154.8$ $\mathrm{pg} / \mathrm{ml}$, respectively. The difference in the concentrations of serum DLD between HCC cases with BCP double mu- 
Table 3. Up- and downregulated proteins in both group A versus group B and group A versus group C

\begin{tabular}{|c|c|c|c|c|c|}
\hline \multirow[t]{2}{*}{ Upregulated protein } & \multicolumn{2}{|c|}{ iTRAQ ratio } & \multirow[t]{2}{*}{ Downregulated protein } & \multicolumn{2}{|c|}{ iTRAQ ratio } \\
\hline & A vs. B & A vs. $\mathrm{C}$ & & A vs. B & A vs. C \\
\hline Complement protein $\mathrm{C} 4 \mathrm{~B}$ & & & \multirow{9}{*}{$\begin{array}{l}\text { DLD } \\
\text { Isoform } 2 \text { of calcium-binding } \\
\text { mitochondrial carrier protein Aralar2 } \\
\text { Isoform } 2 \text { of ribosome-releasing } \\
\text { factor } 2 \text {, mitochondrial }\end{array}$} & 0.788 & 0.693 \\
\hline frameshift mutant & & & & & \\
\hline (fragment) & 3.668 & 2.783 & & 0.62 & 0.595 \\
\hline Keratin, type II cytoskeletal & & & & & \\
\hline 2 epidermal & 2.223 & 2.067 & & 0.542 & 0.582 \\
\hline Hemoglobin subunit beta & 1.595 & 1.331 & & & \\
\hline Isoform M1 of pyruvate & & & & & \\
\hline kinase PKM & 1.494 & 1.382 & & & \\
\hline Eosinophil cationic protein & 1.518 & 1.216 & & & \\
\hline
\end{tabular}

Table 4. Multiple linear regression analysis for factors associated with the development of BCP double mutations

\begin{tabular}{|c|c|c|c|c|c|}
\hline \multirow[t]{2}{*}{ Variable } & \multicolumn{2}{|c|}{$\begin{array}{l}\text { Unstandardized } \\
\text { coefficients }\end{array}$} & \multirow{2}{*}{$\begin{array}{l}\text { Standardized } \\
\text { coefficients } \\
\text { (beta) }\end{array}$} & \multirow[t]{2}{*}{$\mathrm{t}$} & \multirow[t]{2}{*}{$\begin{array}{l}\text { Signifi- } \\
\text { cance }\end{array}$} \\
\hline & B & $\begin{array}{l}\text { standard } \\
\text { error }\end{array}$ & & & \\
\hline (Constant) & 2.057 & 0.127 & & 16.197 & 0.000 \\
\hline Sex & 0.020 & 0.041 & 0.045 & 0.484 & 0.629 \\
\hline Age & 0.033 & 0.026 & 0.114 & 1.274 & 0.205 \\
\hline ALT & 0.106 & 0.043 & 0.243 & 2.463 & 0.015 \\
\hline BCP & -0.096 & 0.041 & -0.223 & -2.352 & 0.020 \\
\hline
\end{tabular}

tations and asymptomatic HBsAg carriers with BCP double mutations was not significant $(t=1.235, \mathrm{p}=0.221)$. However, the difference in the concentrations of serum DLD between the HBsAg-negative group and asymptomatic HBsAg carriers with BCP double mutations or the HBsAg-negative group and the HCC cases with BCP double mutations was significant $(t=4.105, p=0.0001$ and $\mathrm{t}=3.714, \mathrm{p}=0.001$, respectively), suggesting that the concentrations of serum DLD in those infected with HBV are lower.

In order to determine whether there is any difference in the concentrations of serum DLD between HBsAg carriers with $\mathrm{BCP}$ double mutations and those with the wildtype BCP, DLD from asymptomatic HBsAg carriers infected with HBV with the wild-type BCP were tested. The concentration of serum DLD in asymptomatic HBsAg carriers with the wild-type BCP was $167.6 \pm 163.6 \mathrm{pg} / \mathrm{ml}$. The differences between asymptomatic HBsAg carriers infected with HBV with the wild-type BCP and asymp- tomatic $\mathrm{HBsAg}$ carriers with $\mathrm{BCP}$ double mutations or HCC cases with BCP double mutations were significant $(\mathrm{t}=2.376, \mathrm{p}=0.021$, and $\mathrm{t}=2.022, \mathrm{p}=0.048$, respectively). However, the concentrations of serum DLD of asymptomatic carriers with the wild-type BCP were not significantly different from those of HBsAg-negative individuals $(t=1.129, p=0.262)$. These results suggest that lower concentrations of serum DLD in individuals infected with HBV are attributable to BCP double mutations.

Multiple linear regression analysis was carried out to identify the factors that affect the concentrations of serum $\mathrm{DLD}$. The independent variables included sex, age, BCP double mutations and ALT. HBeAg was not included because its correlation with $\mathrm{BCP}$ double mutations is more than 0.8. The results showed that ALT and BCP double mutations were associated with the concentrations of serum DLD $(\mathrm{t}=2.463, \mathrm{p}=0.015$, and $\mathrm{t}=2.352, \mathrm{p}=0.020$, respectively; table 4$)$.

\section{Discussion}

The major finding of this study is that HBV with BCP double mutations is associated with lower concentrations of serum DLD. The initial aim of the study was to identify serum proteins with differential concentrations between HCC patients and HBsAg asymptomatic carriers among individuals infected with $\mathrm{HBV}$ with $\mathrm{BCP}$ double mutations. We found that the relative concentrations of serum DLD differed significantly in the iTRAQ test between HCC patients and HBsAg asymptomatic carriers, and between HCC patients and HBsAg-negative individuals. However, only the difference between HCC patients and HBsAg-negative individuals could be confirmed by 
ELISA. Meanwhile, we found that the concentrations of serum DLD in those infected with HBV with BCP double mutations is significantly lower than individuals with the wild-type BCP. However, the difference was not seen between individuals with the wild-type BCP and those negative for HBsAg. Clearly, HBV with BCP double mutations are associated with lower concentrations of serum DLD.

There have been some studies aiming to identify serum biomarkers of HCC for early diagnosis using iTRAQ. These have compared proteins differentially expressed in serum between HCC and chronic hepatitis B patients [15, 16]. In this study, we selected controls from those infected with $\mathrm{HBV}$ with $\mathrm{BCP}$ double mutations, representing individuals who have been confirmed to be at highest risk for the development of HCC [12].

DLD is the common flavoprotein component of the three mammalian $\alpha$-keto acid dehydrogenase complexes, namely the pyruvate dehydrogenase complex, the $\alpha$-ketoglutarate dehydrogenase complex and the branchedchain $a$-keto acid dehydrogenase complex. The DLD component is also present in the glycine cleavage system [17]. DLD has multiple roles in the energy metabolism and redox balance and is present in at least four multienzyme complexes [18]. A deficiency of DLD may lead to a range of presentations, mostly characterized by severe neurological impairment in early childhood with encephalopathy and seizures $[19,20]$. Liver injury is one of the results of DLD deficiency. Affected individuals frequently experience lifelong recurrent attacks of hepatopathy [21].

The association of viral infection with autoantibodies has been strongly suggested. Epstein-Barr virus, hepatitis $B$ and $C$ viruses, human immunodeficiency virus and human parvovirus B19 appear to be associated with autoantibodies more frequently than other viruses. Several studies have suggested that chronic HBV or HCV may act as a trigger factor for the development of autoimmune rheumatic diseases [22]. Autoantibodies are common in chronic HBV infection [23, 24]. Autoantibody formation may occur in children with chronic HBV infection [25]. DLD has been found to be a major autoantigen in hepatitis $C$ virus infection [26] and a target of autoantibodies in endometrial cancer [27].

$\mathrm{BCP}$ double mutations were first described in the core promoter of HBV from Japanese patients [7, 28]. Subsequently, we and others found that the double mutations are associated with more severe liver diseases, including HCC [8-11]. The association between the double mutations and HCC has been confirmed by prospective studies
$[12,29,30]$. However, the mechanisms of oncogenesis of BCP double mutations remain obscure.

The development of BCP double mutations is the result of immune selection [31] and the selection consolidates the persistence of HBV infection [32]. In this study, we found that individuals infected with HBV with BCP double mutations have lower concentrations of serum DLD than those with the wild-type BCP. It may be postulated that $\mathrm{BCP}$ double mutations may induce more autoantibody against DLD, resulting in lower concentrations of serum DLD. If so, it is not difficult to understand that $\mathrm{BCP}$ double mutations are associated with more severe liver diseases because the DLD deficiency may cause liver injury [21]. This may be one of the clues for the study of the mechanisms of oncogenesis of BCP double mutations.

Serum concentrations of ALT have been regarded as markers of liver injury, including a wide range of etiologies from viral hepatitis to fatty liver [33]. We found that the level of ALT is associated with the concentration of serum DLD. Sex and age were not found to be associated with the concentrations of serum DLD in this study. We did not determine the concentrations of DLD in acute and chronic hepatitis and liver cirrhosis but are planning to answer these questions in the future. Furthermore, a comparison of the concentrations of autoantibody against DLD between those infected with HBV with BCP double mutations and those with the wild-type BCP may help determine whether the mutations induce more autoantibodies against DLD.

\section{Acknowledgements}

We are indebted to the staff members of Long An Sanitary and Antiepidemic Station and local hospitals in Long An county, Guangxi, who assisted in sample collection. This study was supported by the Wellcome Trust (WT072058MA) and the Guangxi Program for Scientific Research and Technology Development (Gui Ke Gong 1140003A-37).

\section{Disclosure Statement}

No conflicts of interest exist for any of the authors.
Jiang/Chen/Harrison/Li/Wang/Li/Hu/Li/ Yang/Tan/Fang 


\section{References}

1 Mittal S, El-Serag HB: Epidemiology of hepatocellular carcinoma: consider the population. Clin Gastroenterol 2013;47(suppl):S2S6.

2 McGlynn KA, London WT: Epidemiology and natural history of hepatocellular carcinoma. Best Pract Res Clin Gastroenterol 2005; 19:3-23.

3 Maupas P, Melnick JL: Hepatitis B infection and primary liver cancer. Prog Med Virol 1981;27:1-5.

4 Tiollais P, Pourcel C, Dejean A: The hepatitis $B$ virus. Nature 1985;317:489-495.

5 Kramvis A, Kew MC: The core promoter of hepatitis B virus. J Viral Hepat 1999;6:415427.

6 Harrison TJ: Hepatitis B virus: molecular virology and common mutants. Sem Liver Dis 2006;26:87-96.

7 Okamoto H, Tsuda F, Akahane Y, Sugai Y, Yoshiba M, Moriyama K, Tanaka T, Miyakawa Y, Mayumi M: Hepatitis B virus with mutations in the core promoter for an e antigennegative phenotype in carriers with antibody to e antigen. J Virol 1994;68:8102-8110.

8 Nagasaka A, Hige S, Marutani M, Tsunematsu I, Saito M, Yamamoto Y, Konishi S, Asaka M: Prevalence of mutations in core promoter/ precore region in Japanese patients with chronic hepatitis B virus infection. Dig Dis Sci 1998;43:2473-2478.

9 Fang ZL, Ling R, Wang SS, Nong J, Huang CS, Harrison TJ: HBV core promoter mutations prevail in patients with hepatocellular carcinoma from Guangxi, China. J Med Virol 1998;56:18-24.

10 Fang ZL, Yang J, Ge X, Zhuang H, Gong J, Li $\mathrm{R}$, Ling R, Harrison TJ: Core promoter mutations $\left(\mathrm{A}_{1762} \mathrm{~T}\right.$ and $\left.\mathrm{G}_{1764} \mathrm{~A}\right)$ and viral genotype in chronic hepatitis $\mathrm{B}$ and hepatocellular carcinoma in Guangxi, China. J Med Virol 2002; 68:33-40.

11 Kao JH, Chen PJ, Lai MY, Chen DS: Basal core promoter mutations of hepatitis $B$ virus increase the risk of hepatocellular carcinoma in hepatitis B carriers. Gastroenterology 2003; 124:327-334.

12 Fang ZL, Sabin CA, Dong BQ, Ge LY, Wei SC, Chen QY, Yang JY, Huang J, Wang XY, Harrison TJ: HBV A1762T, G1764A mutations are a valuable biomarker for identifying a subset of male HBsAg carriers at extremely high risk of hepatocellular carcinoma: a prospective study. Am J Gastroenterol 2008;103: 2254-2262.
13 Chaerkady R, Harsha HC, Nalli A, Gucek M, Vivekanandan P, Akhtar J, Cole RN, Simmers J, Schulick RD, Singh S, Torbenson M, Pandey A, Thuluvath PJ: A quantitative proteomic approach for identification of potential biomarkers in hepatocellular carcinoma. J Proteome Res 2008;7:4289-4298.

14 Bradford MM: A rapid and sensitive method for the quantitation of microgram quantities of protein utilizing the principle of proteindye binding. Anal Biochem 1976;72:248-254.

15 He X, Wang Y, Zhang W, Li H, Luo R, Zhou Y, Liao CL, Huang H, Lv X, Xie Z, He M: Screening differential expression of serum proteins in AFP-negative HBV-related hepatocellular carcinoma using iTRAQ-MALDIMS/MS. Neoplasma 2014;61:17-26.

16 Liu Y, Wang X, Li S, Hu H, Zhang D, Hu P, Yang Y, Ren H: The role of von Willebrand factor as a biomarker of tumor development in hepatitis B virus-associated human hepatocellular carcinoma: a quantitative proteomic based study. J Proteomics 2014;106:99-112.

17 Johanning GL, Morris JI, Madhusudhan KT, Samols D, Patel MS: Characterization of the transcriptional regulatory region of the human dihydrolipoamide dehydrogenase gene. Proc Natl Acad Sci USA 1992;89:1096410968.

18 Babady NE, Pang YP, Elpeleg O, Isaya G: Cryptic proteolytic activity of dihydrolipoamide dehydrogenase. Proc Natl Acad Sci USA 2007;104:6158-6163.

19 Craigen WJ: Leigh disease with deficiency of lipoamide dehydrogenase: treatment failure with dichloroacetate. Pediatr Neurol 1996;14: 69-71.

20 Grafakou O, Oexle K, van den Heuvel L, Smeets R, Trijbels F, Goebel HH, Bosshard N, Superti-Furga A, Steinmann B, Smeitink J: Leigh syndrome due to compound heterozygosity of dihydrolipoamide dehydrogenase gene mutations: description of the first E3 splice site mutation. Eur J Pediatr 2003;162: 714-718.

21 Quinonez SC, Thoene JG: Dihydrolipoamide dehydrogenase deficiency; in Pagon RA, Adam MP, Ardinger HH, Wallace SE, Amemiya A, Bean LJH, Bird TD, Dolan CR, Fong CT, Smith RJH, Stephens K (eds): GeneReviews. Seattle, University of Washington, 2014.

22 Cacoub P, Terrier B: Hepatitis B-related autoimmune manifestations. Rheum Dis Clin North Am 2009;35:125-137.

23 Gregorio GV, Jones H, Choudhuri K, Vegnente A, Bortolotti F, Mieli-Vergani G, Vergani $\mathrm{D}$ : Autoantibody prevalence in chronic hepatitis B virus infection: effect in interferon alfa. Hepatology 1996;24:520-523.
24 Li BA, Liu J, Hou J, Tang J, Zhang J, Xu J, Song YJ, Liu AX, Zhao J, Guo JX, Chen L, Wang H, Yang LH, Lu J, Mao YL: Autoantibodies in Chinese patients with chronic hepatitis $\mathrm{B}$ : prevalence and clinical associations. World J Gastroenterol 2015;21:283-291.

25 Kansu A, Kuloğlu Z, Demirçeken F, Girgin N: Autoantibodies in children with chronic hepatitis $B$ infection and the influence of interferon alpha. Turk J Gastroenterol 2004;15: 213-218.

26 Wu YY, Hsu TC, Chen TY, Liu TC, Liu GY, Lee YJ, Tsay GJ: Proteinase 3 and dihydrolipoamide dehydrogenase (E3) are major autoantigens in hepatitis $\mathrm{C}$ virus (HCV) infection. Clin Exp Immunol 2002;128:347-352.

27 Yoneyama K, Shibata R, Igarashi A, Kojima S, Kodani Y, Nagata K, Kurose K, Kawase R, Takeshita T, Hattori S: Proteomic identification of dihydrolipoamide dehydrogenase as a target of autoantibodies in patients with endometrial cancer. Anticancer Res 2014;34: 5021-5027.

28 Sato S, Suzuki K, Akahane Y, Akamatsu K, Akiyama K, Yunomura K, Tsuda F, Tanaka T, Okamoto H, Miyakawa Y, Mayumi M: Hepatitis $B$ virus strains with mutations in the core promoter in patients with fulminant hepatitis. Ann Intern Med 1995;122:241-248.

29 Yuen MF, Tanaka Y, Fong DY, Fung J, Wong DK, Yuen JC, But DY, Chan AO, Wong BC, Mizokami M, Lai CL: Independent risk factors and predictive score for the development of hepatocellular carcinoma in chronic hepatitis B. J Hepatol 2009;50:80-88.

30 Chu CM, Lin CC, Lin SM, Lin DY, Liaw YF: Viral load, genotypes, and mutants in hepatitis $B$ virus-related hepatocellular carcinoma: special emphasis on patients with early hepatocellular carcinoma. Dig Dis Sci 2012;57: 232-238.

31 Nie H, Evans AA, London WT, Block TM, Ren XD: Quantitative dynamics of hepatitis B basal core promoter and precore mutants before and after $\mathrm{HBeAg}$ seroconversion. J Hepatol 2012;56:795-802.

32 Sendi H, Mehrab-Mohseni M, Shahraz S, Norder H, Alavian SM, Noorinayer B, Zali MR, Pumpens P, Bonkovsky HL, Magnius LO: CTL escape mutations of core protein are more frequent in strains of $\mathrm{HBeAg}$ negative patients with low levels of HBV DNA. J Clin Virol 2009;46:259-264.

33 Pratt DS, Kaplan MM: Evaluation of abnormal liver-enzyme results in asymptomatic patients. N Engl J Med 2000;342:1266-1271. 